Grzegorz MENTEL ${ }^{1}$

\title{
ENERGY MARKET IN THE CONTEXT OF LONG-TERM FORECASTS
}

The paper presents simulations of long-term forecasts concepts of the energy market in Poland. The study was based on the quotations conducted on the Polish Power Exchange. The methodology of analysis was based on a risk analysis of securities and more specifically on the the Value at Risk. On the basis of that measure there were conducted forecasts with a longer time horizon both for the quotations of the major indexes of the above exchange as well as the stock price changes which take place every day.

\section{INTRODUCTION}

The study involved indexes quoted on the Polish Power Exchange in the period from 1 January 2008 to 30 June 2012. Quotations are carried out in a daily system, therefore, the number of observations that has been analyzed is quite large. The essence of such a long time horizon adopted for the analysis was the fact that the energy market has changed in the time of financial crisis of the last years of the last decade.

However, the main aspect was the desire for a long-term forecasting for this type of market. The methodology used for the securities listed on the Warsaw Stock Exchange is in fact known. However, there is no extensive knowledge of the ratios, and thus the implications of these methods for both energy markets and other carriers.

The study is limited to the estimation of forecasts based on simulation methods and, therefore, a well-known historical simulation and Monte Carlo methods. These other approaches do not require the estimation of the distribution parameters that should be determined by parametric methods, which would not necessarily give satisfactory results. An additional advantage of such inference is the fact of risk analysis of this type of quotations in the context of $V a R$ analysis. This methodology provides a starting point for long-term forecasts later designated both for the main courses of Polish Power Exchange as well as the daily changes of its quotations.

\section{POLISH POWER EXCHANGE AND THE RULES OF ITS TURNOVER}

As for the energy mass trading in Poland, it is indicated at the outset by the market called the Polish Power Exchange. This creation was literally at the end of the last century because in 1999 and it is the only exchange which has received a license from the Polish Financial Supervision Authority (PFSA) to run a commodity exchange. In the six months

\footnotetext{
${ }^{1}$ Ph.D., Grzegorz Mentel, Department of Quantitative Methods, The Faculty of Management, Rzeszow University of Technology, Rzeszow.
} 
since its registration the first spot market ${ }^{2}$ started its operations for the energy, widely known as Day-Ahead Market (Figure 1).

Polish Power Exchange is the "product" which is based on the Stock Exchange in Warsaw and to a large extent is governed by similar mechanisms. Just like on the Stock Exchange there are held here regular (daily) quotations of buying and selling goods, which in this case is energy. In addition to individuals and firms in the floor there is a whole host of brokers who let, of course apart from the stock trading system, for the smooth arranging of the transactions.

An important issue for this type of regulated markets is the fact that all participants have an equal access to market information and, what is the most important, the rule of making transactions for all participants are open, transparent and equal. Thus, each participant is equal on the market without favoring either side. In addition, by automating the process of finding the best deal PPE reduces the cost of negotiations. The advantage is also considerable flexibility when entering into transactions, which in some ways allows to manage commercial risk.

Fig 1. The values of DAM indexes in the analysed period in PLN/MWh.

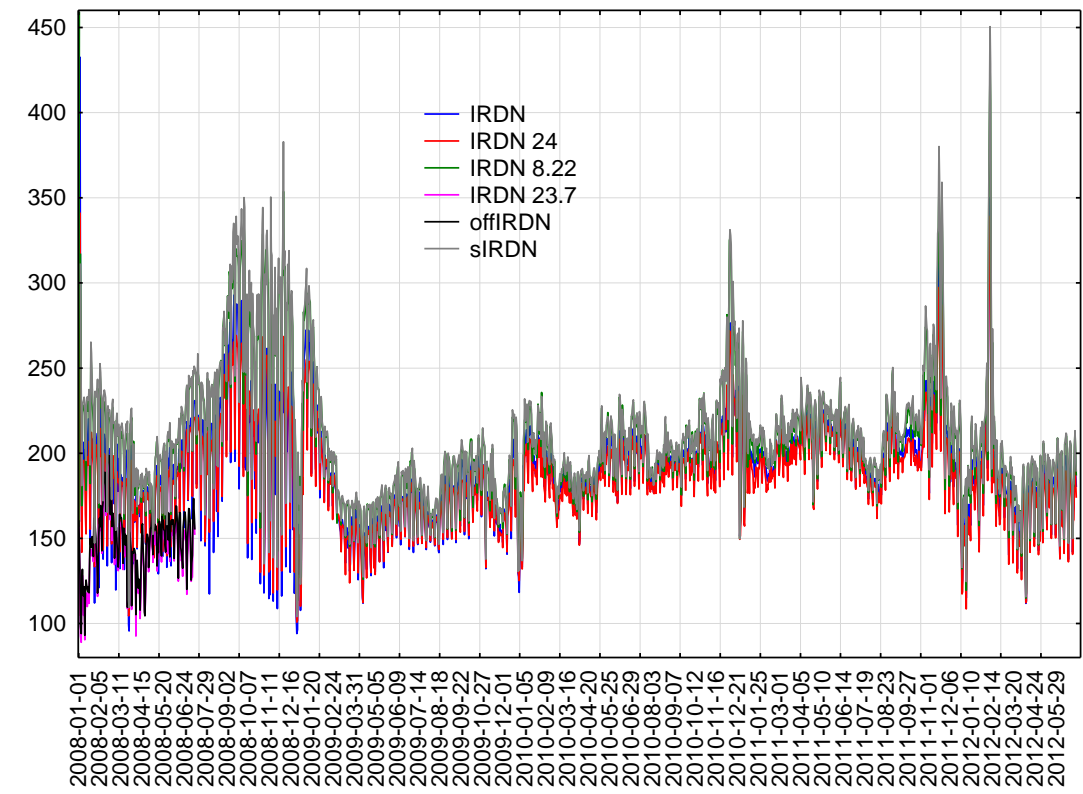

Source: Own study.

Over the years PPE has developed the following areas of activity:

- Day-Ahead Market (DAM)

- Commodity Derivatives Market (CDM),

- Intra Day Market (IDM)

\footnotetext{
${ }^{2}$ Spot market - a market in which, in this case, the goods are sold to dispose them immediately. There is a second type commonly known as the forward market, where a promise to buy or sell goods are determined on a specific date in the future, but at a price fixed at the time of the transaction.
} 
- Property Rights Market for RES and CHP (PRM)

- Emission Allowances Market (CO2 Spot) (EAM).

Due to the extensive nature of the areas described above there were analyzed only DAM indexes, which is a typical physical market. The result of the transaction included here is the physical flow of energy. Thus, the market is mainly for manufacturers and retailers of this type of energy and the companies doing so-called wholesale.

\section{VALUE AT RISK IN THE ANALYSIS OF EXCHANGE RATE RISK}

Very often as a tool to assess the risk of investing there are used methods based on the analysis of time series. The risk of investing in a commodity market or directly securities, results from the exchange rates volatility. Hence, while assessing the risk it is very important to estimate the expected appropiate variation.

Furthermore, the investor is interested in getting to know accurately the maximum risk of the potential losses. This risk is often expressed by the value of the maximum possible loss that may be incurred by the investor in the value of its investment portfolio in the worst assumed scenario.

On this principle is based a risk assessment method to invest in the stock market, which consists in estimating the so-called. "value of the portfolio at risk", known as $\mathrm{VaR}$ (Value at Risk).

This method estimates the maximum potential loss in portfolio value during the assumed time series (e.g. one day, one week) in such a way that the probability of the situation that the losses would be even higher is very small (equal to the adopted level of significance).

Generally, the methods for estimating VaR can be divided into two types: simulation methods (mainly historical simulation and Monte Carlo simulation) and analytical methods (based on a variety of models describing the "behavior" of financial instruments in its investment portfolio). The third one is the group of semiparametric methods ${ }^{3}$.

In the historical simulation method for estimating $V a R$ there is used the actual data, which is better than in case of other classical methods as it reflects the actual behavior of the market. The main advantage of this method is that it is a non-parametric method. This means that on the one side there is no restriction resulting from the need for the assumption of normality, and on the other hand the estimation of some parameters (such as mean and standard deviation) on the basis of historical data ${ }^{4}$ is avoided.

In case of "fat tails" in the real distribution of prices, historical simulation method gives a more reliable level of $\mathrm{VaR}$. The advantage of the historical simulation is that, in contrast to other methods it is easier to estimate.

Historical approach is a very intuitive method of estimating Value at Risk. It is determined based on historical rates of return of the given instrument (or portfolio) and their empirical distribution. It is important for the rate of return to be calculated on the period for which $V a R$ is calculated (if the investment horizon is one day, then the rate of return should be determined daily).

\footnotetext{
${ }^{3}$ Mentel G., Ryzyko rynku akcji, Wydawnictwo Fachowe CeDeWu, Warszawa 2012, s. 50-51.

${ }^{4}$ Jajuga K., Metody ekonometryczne i statystyczne $w$ analizie rynku kapitałowego, Wydawnictwo Akademii Ekonomicznej im. Oskara Langego we Wrocławiu, Wrocław 2000, s. 112 i dalsze.
} 
An interesting approach in this regard is to generate VaR based on the so-called profit and loss $(P \& L)$. This solution is recommended by RiskMetrics ${ }^{\mathrm{TM}}$ Group, calculating the risky value determined on the basis of profit and loss scenarios ${ }^{5}$. At such an approach, there are calculated the potential prices of values at $t$ period

$$
P_{t}=P_{0} \cdot e^{r \sqrt{t}}
$$

where:

$P_{t} \quad$ - stock price in $t$ period,

$P_{0} \quad$ - stock price in the initial period,

$r \quad$ - already determined return rate,

$t \quad$ - time horizon for which $V a R$ is determined,

and then the differences of prices $P_{0}$ and scenarios $P_{t}$ are generated.

Figure 2. VaR value for return rates for SIRDN24 index in the analyzed period at the significance level of $\alpha=0,05$ - historical simulation.

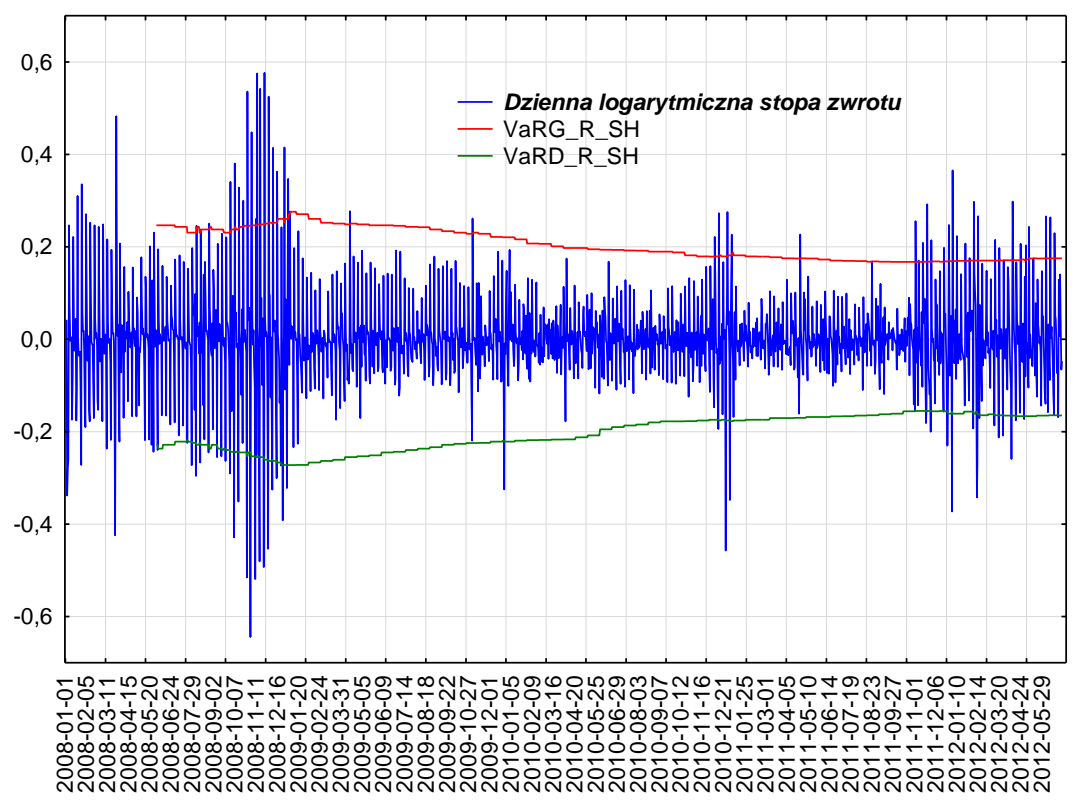

Source: Own study.

The differences determined in such a way are subjected to ordering process and then the percentile is determned which corresponds to the required level of confidence - in this way the $V a R$ is obtained.

While using historical model it is important to collect a large series of data. The greater their number, the greater the accuracy. However, the data is often very distant outof-date, and is not as important as the data less distant. Sometimes gathering a sufficient number of data is not possible and the use of this method is then limited.

${ }^{5}$ Mina J., Yi Ciao J., Return to Risk Metrics: The Evalution of a Standard, Risk Metrics Technical Documents, New York 2001, s. 26. 
This method of calculating $V a R$ is sensitive to extreme return rates included in the distribution. As a result, the size of Value at Risk changes in a "stepped" way and the size of the risk is often underestimated or overestimated (Figure 2).

Monte Carlo simulation, in turn, is based on a hypothetical stochastic model that describes the shaping of the prices of the financial instrument. The essence of the stochastic processes is that it is not possible to predict the values of the process, one can only determine the probability that a given value is reached with.

Figure 3. VaR value for return rates for sIRDN24 index in the analyzed period at the significance level of $\alpha=0,05$ - Monte Carlo simulation.

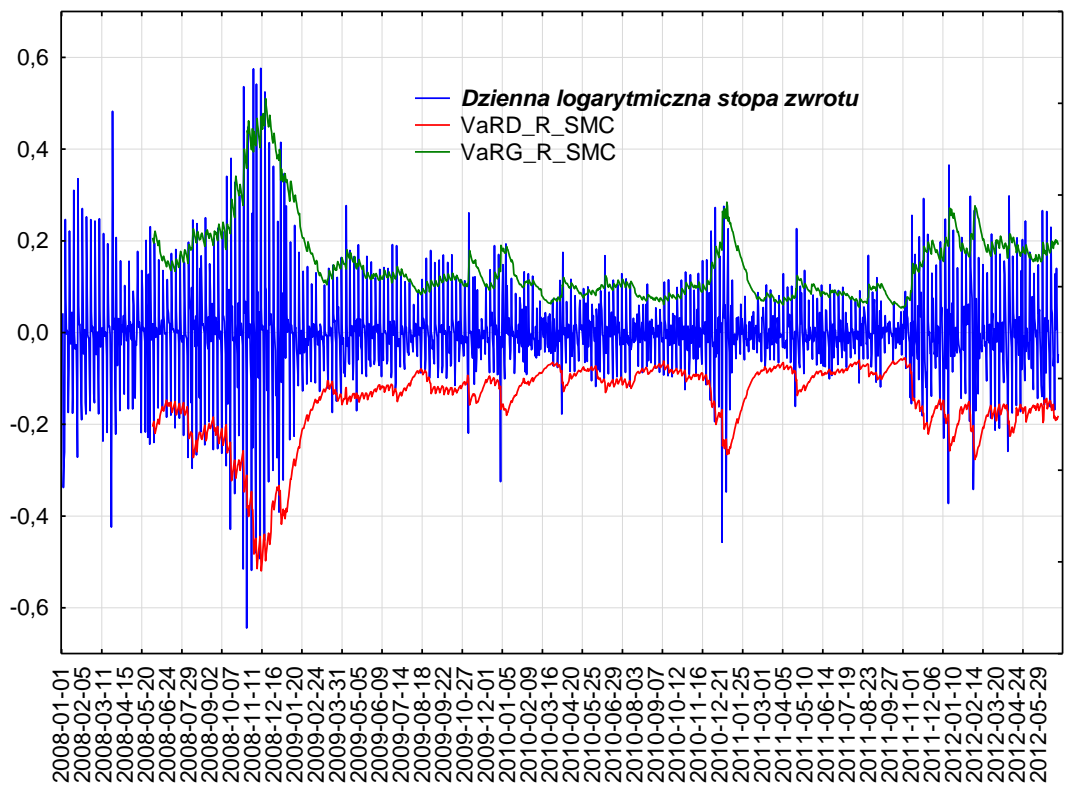

Source: Own study.

The process value is dependent only on the time and the previous value of the process. In the Monte Carlo method it is assumed a hypothetical model that describes the mechanism of the formation of prices (or return rates) of financial instruments. It is often assumed that this process is a geometric Brownian motion. Using as a basis this or other models (model "mean reverting"6 ${ }^{16}$ jump diffusion model ${ }^{7}$, etc.) there are generated a lot of observations of financial instruments prices. In this way it is obtained the distribution of return rates of the financial instrument. Determination of the quantile of this distribution allows for the direct $V a R$ determination (Figure 3). The process parameters are usually estimated based on historical data ${ }^{8}$.

\footnotetext{
${ }^{6}$ „Mean reverting” model is often called Ornstein-Uhlenbeck model

${ }^{7}$ „Mean reverting” model is often called Ornstein-Uhlenbeck model

${ }^{8}$ Jajuga K., Kuziak K., Papla D., Ryzyko wybranych instrumentów polskiego rynku finansowego - część I, Rynek Terminowy 6/99, s. 133 i dalsze.
} 
In order to determine the predicted variance of the returns of stock prices, one can use the equation used by RiskMetrics ${ }^{\mathrm{TM}}$ in their classic models:

$$
\sigma_{t}^{2}=(1-\lambda) r_{t}^{2}+\lambda \sigma_{t-1}^{2}
$$

Estimation variances of stock price returns for time $t$ obtained in accordance with the above formula is a weighted arithmetic mean (with weights $1-\lambda$ oraz $\lambda$ ) for share price returns in the square at the time $t$ and the previous estimate of variance returns at time $t-1$. For daily returns in the classical model of RiskMetrics ${ }^{\mathrm{TM}}$ it is applied a universal constant smoothing rate of $\lambda=0,97^{9,10}$.

Moving directly to evaluation of the effectiveness of Value at Risk estimated for individual indexes for DAM indexes, it is worth determining the percentage of exceedances interest beyond the acceptable one, with an adopted acceptable level of significance adopted, a five-per cent threshold (Table 1).

Table 1. The value of the exceedances interest of confidence intervals for the mutual level of significance $\alpha=0,05$.

Source: Own study

\begin{tabular}{|c|c|c|}
\hline & \multicolumn{2}{|c|}{ Historical simulation } \\
\hline & lower & upper \\
\hline IRDN & 6,028131279 & 6,630944407 \\
\hline sIRDN & 4,88948426 & 8,171466845 \\
\hline IRDN 8.22 & 4,487608841 & 8,774279973 \\
\hline IRDN 23.7 & 9,523809524 & 9,523809524 \\
\hline IRDN 24 & 5,559276624 & 8,238446082 \\
\hline \multirow[t]{3}{*}{ off IRDN } & 7,142857143 & 9,523809524 \\
\hline & \multicolumn{2}{|c|}{ Monte Carlo simulation } \\
\hline & lower & upper \\
\hline IRDN & 2,478231748 & 2,880107167 \\
\hline sIRDN & 3,415941058 & 3,081044876 \\
\hline IRDN 8.22 & 3,75083724 & 3,081044876 \\
\hline IRDN 23.7 & 4,761904762 & 7,142857143 \\
\hline IRDN 24 & 2,947086403 & 3,415941058 \\
\hline off IRDN & 7,142857143 & 4,761904762 \\
\hline
\end{tabular}

As one can easily observe lower limits of the determined confidence intervals which constitute $V a R$ are different for the discussed methods. Historical simulation in only two cases gives satisfactory results, while in other cases, the percentage of exceedances beyond the permissible limit is significant. Whereas value at risk determined by using Monte Carlo simulation in only one case is not contained within five-per cent threshold, and most importantly, flexibility and response to market changes is incomparably better than in the case of the first-mentioned method.

But we must remember that the energy trading market is not synonymous with market of securities. In the case of shares it is more about investment in uplift rates, or to draw the

\footnotetext{
${ }^{9}$ Mina J., Yi Ciao J., Return to Risk Metrics: The Evaluation of a Standard, Risk Metrics Technical Documents, New York 2001, s. 15.

${ }^{10}$ The optimal number of historical observations taken at the level of the smoothing constant is $\mathrm{n}=151$. Such a value was taken into account in the conducted analyzes.
} 
greatest possible profit. However, when it comes to energy while doing purchase / sale, rather we deal with creating the energy market, both from the buyer and the manufacturer. Cheaper energy - from the buyer's side - means higher profits. From the manufacturer's side Commodity Exchange, and more specifically its markets and quatiations carried out on them, yet allow for the indirect valuation of energy companies. This is done by measuring the product manufactured by them, in this case energy. Of course, the additional information form quotations for manufacturers are signals concerning investment within the developing of new power capacity.

\section{LONG-TERM CONE FORECASTS}

Assuming that the main component of $V a R$ is to identify the future state of the asset, one should attempt to generate a subsequent study of the variable. Measure of Value at Risk itself allows for some predictability in future periods, but usually these horizons are not too large. Thus, it becomes important to obtain the possibility of future values for longer periods of time.

Within this range it is possible to use the presented models that after the appropiate conversion allow to generate long-term forecasts for expected price of the discussed instruments (e.g. the forecast horizon $h=100$ days $^{11}$ ). For this type of forecast the estimated variance of prices return, depending on the variance for the daily returns is as follows:

$$
\begin{aligned}
& \sigma_{t+h \mid t}^{2}=h \cdot \sigma_{t+1 \mid t}^{2}, \\
& \sigma_{t+h \mid t}=\sqrt{h} \cdot \sigma_{t+1 \mid t} .
\end{aligned}
$$

Based on the above formula, due to scaling of the long-term variation by the forecast horizon $h$ one can get so-called "forecast cones".

They provide an overall view of the future behavior of $V a R$, and thus also to the general trend, which will rule on the market of the given value. Therefore, the determination of such values of Value at Risk allows investors to allocate better their resources and greater predictability of the effects of their investments. As an example of the graphical display can be used the quotations of sIRDN index (Figure 4).

\footnotetext{
${ }^{11}$ While determining the long-term forecast it was assumed the forecast horizon $h$ equal to 100 days, i.e. 20 stock market weeks. The aim was to show better the same cone forecasts, as well as the behavior of the exchange rate or the profit / loss for the designated cones. Shorter periods do not allow for a good graphic presentation and draw specific conclusions as it is hard to illustrate the behavior of the exchange rates in relation to the designated forecasts.
} 
Figure 4. VaR forecast cones for exchange rate of sIRDN index in the analyzed period at the significance level of $\alpha=0,05$ - historical and Monte Carlo simulation.

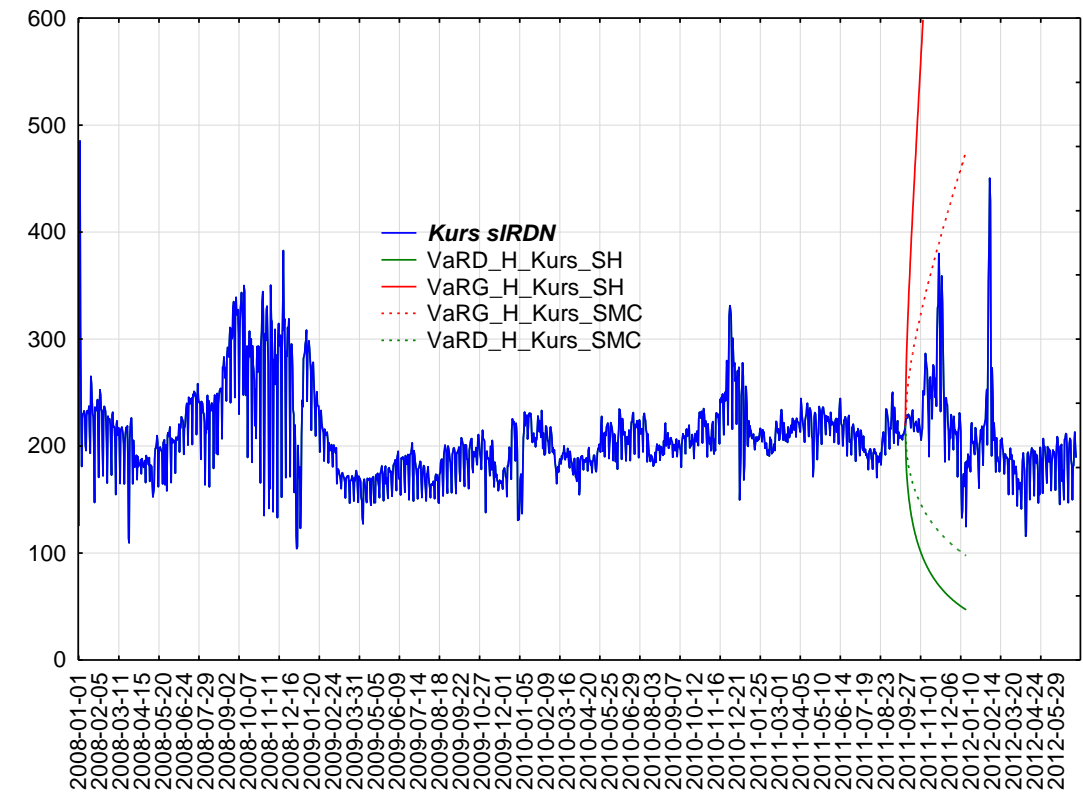

Source: Own study.

As one can see, similarly to the same assessment of short-term forecasts of potential losses also here there is a large discrepancy between the methods. Again, much better indication, based on bactesting gives Monte Carlo simulation. In case of the historical method the inflation of the rate forecasts decline is significant. Not to mention the predictions of possible increases in the sIRDN index. No quick reaction to market changes noticed in the analysis of return rates has its meaning also in this case. Flexibility in adjusting is much greater at the Monte Carlo method.

While analyzing profit and loss $(P \& L)$ (Figure 5), it can only be confirmed the previously observed trends. The change of methods for profits / losses is the same as in the case of long-term forecasts of sIRDN index. So one can see some kind of repeatiblity in the indications. The situation is similar when analyzing other considered DAM indexes. 
Figure 5. VaR forecast cones for profits/loss of sIRDN index in the analyzed period at the significance level of $\alpha=0,05$ - historical and Monte Carlo simulation.

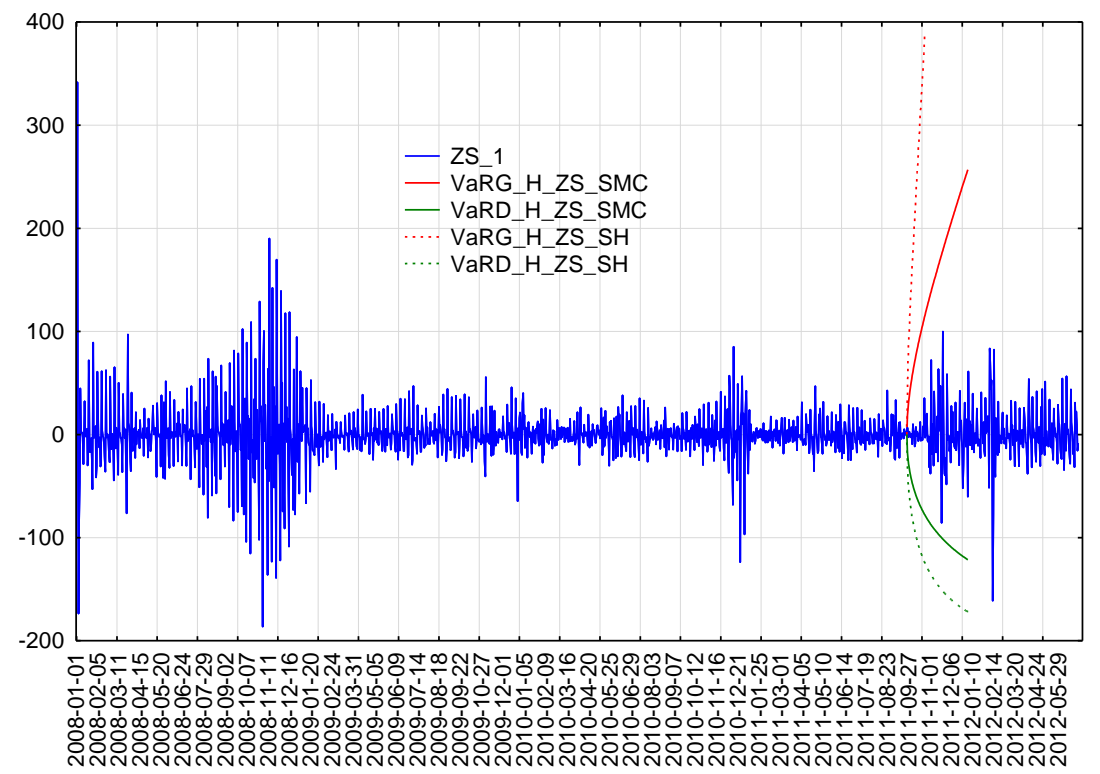

Source: Own study.

\section{CONCLUSIONS}

An analysis of simulation forecasting methods on energy market quite clearly indicates the effectiveness of the generated in this case predictions. Monte Carlo method as mentioned earlier gives a much better indications for the future than it is in the case of the other already discussed method. The historical method due to the specific methodology does not respond flexibly to market changes. In addition, both short-term forecasts and long-term ones are very inflated resulting in a kind of aversion market. It should be emphasized that both methods overstate the forecast of future exchange rate behavior. In general, certain groups of parametric methods are in this case much better ${ }^{12}$. The question, however, is the selection of the appropriate model of random modelled faults.

There is also noticeable a significant correlation between the market trend and the value of the cone tail of the forecast. In addition, a significant impact on the shape of cones arms have historical observations immediately preceding the forecast period. Thus, the relationship between the designated forecasts and the character of the quotations for which they are estimated is visible ${ }^{13}$.

As for the analysis of the energy market and the Polish Power Exchange it is worth showing its full liberalization nowadays. Thanks to the market transaction of purchase and sales one can talk about the market mechanisms of determining the energy price, and yet this is probably the point. In addition, the Exchange itself offers the possibility to appoint

\footnotetext{
${ }^{12}$ Mentel G., Value at Risk $w$ warunkach polskiego rynku kapitalowego, Wydawnictwo Fachowe CeDeWu, Warszawa 2011, s. 140 i dalsze.

${ }^{13}$ Ibidem, s. 187.
} 
an objective market price which is the benchmark for other transactions for this type of market. So we can talk about the price shaping based on supply and demand, thus creating a "reliable" market value.

\section{REFERENCES:}

[1] Jajuga K., Kuziak K., Papla D., Ryzyko wybranych instrumentów polskiego rynku finansowego - część I, Rynek Terminowy 6/99

[2] Jajuga K., Metody ekonometryczne i statystyczne w analizie rynku kapitałowego, Wydawnictwo Akademii Ekonomicznej im. Oskara Langego we Wrocławiu, Wrocław 2000

[3] Mentel G., Ryzyko rynku akcji, Wydawnictwo Fachowe CeDeWu, Warszawa 2012.

[4] Mentel G., Value at Risk w warunkach polskiego rynku kapitatowego, Wydawnictwo Fachowe CeDeWu, Warszawa 2011

[5] Mina J., Yi Ciao J., Return to Risk Metrics: The Evaluation of a Standard, Risk Metrics Technical Documents, New York 2001

[6] Shahriar S., Erkan T., A long-term view of worldwide fossil fuel prices, Applied Energy 87(2010).

\section{RYNEK ENERGII ELEKTRYCZNEJ W KONTEKŚCIE PROGNOZ DLUGO- TERMINOWYCH}

W artykule przedstawiono symulacyjne koncepcje prognoz długoterminowych rynku energii elektrycznej w Polsce. Badania oparto o notowania prowadzone na Towarowej Giełdzie Energii S.A.

Metodyka analiz oparta została o analizę ryzyka papierów wartościowych, a dokładniej wartość zagrożoną na ryzyko, czyli Value at Risk. Na bazie tejże miary zostały przeprowadzone prognozy o dłuższym horyzoncie czasowym, zarówno dla samych notowań kwotowych głównych indeksów ww. giełdy, jak i zmian cenowych, jakie dokonują się z dnia na dzień.

DOI: 10.7862/rz.2012.zim.25 